\title{
Web-based Autonomous Learning in the Chinese EFL Setting
}

\author{
Qiyuan Shen \\ School of Foreign Languages, Jiangxi Normal University, Nanchang 330022, China
}

\begin{abstract}
The Chinese Ministry of Education promulgated College English Curriculum Requirements in 2007, according to which we should not only cultivate the college students' comprehensive qualities but also develop their autonomous learning ability. In the meantime, a Computer- and Classroom-Based College English Teaching Model, which was supposed to be an effective way of developing autonomous learning ability, was also put forward. For this reason, the present article explored whether a web-based autonomous learning setting could improve the college students' overall English performance more effectively than the traditional English teaching setting. After two school years' experiment, a t-test was made to compare the scores of Band 4 College English Test between the control group and the experimental group. Questionnaires were also conducted to investigate the experimental group's attitude toward web-based autonomous learning and the expected roles of an English teacher in such a learning setting. The t-test result indicated that the experimental group outperformed the control group in the Band 4 College English Test. Questionnaires showed that more than three fourths of the participants in the experimental group were satisfied with the web-based autonomous learning setting. As for the roles of an English teacher, they were expected to be counselors, facilitators and motivators first and foremost.
\end{abstract}

Index Terms - web-based autonomous learning, the expected roles, the Chinese EFL setting

\section{INTRODUCTION}

With the rapid development of information technology, computer and networks have been extensively used in English language teaching programs. At the same time, many countries have been reforming English language teaching models according to web-based teaching theory and practice. For this reason, the Chinese Ministry of Education promulgated College English Curriculum Requirements in 2007, according to which we should not only cultivate the college students' comprehensive qualities but also develop their autonomous learning ability. In the meantime, a Computer- and Classroom-Based College English Teaching Model, which was supposed to be an effective way of developing autonomous learning ability, was also put forward. Since then, college English teaching reforms have been carrying out in full swing in the Chinese colleges and universities.

Aiming at improving the students' comprehensive English abilities, college English teaching reforms in China have always been trying to replace the traditional teacher-centered teaching model with the student-centered teaching model because the latter focuses on imparting language knowledge and skills as well as cultivating the students' language usage ability and autonomous learning ability. With the support of computer and networks, this new teaching model tries to integrate web-based autonomous learning into English teaching classrooms, by way of which the concepts of personalized learning and learner autonomy can be well embodied. However, for the Chinese undergraduates who have got accustomed to traditional English teaching models, web-based autonomous leaning can be both an opportunity and a challenge.

\section{LITERATURE REVIEW}

The web-based English teaching model was established under the background of constructivism learning theory which came into existence in the 1960s. According to this theory, people construct their own understanding and knowledge of the world through experiencing things and reflecting on those experiences. By making use of the necessary resources, a learner in a certain social cultural environment obtains knowledge through meaning building with the help of other people. Therefore, a constructivism learning situation consists of the following elements: environment creation, conversation negotiation and information provision.

The constructivism learning theory regulates that the role of instructors has to be adapted to be facilitators instead of teachers (Bauersfeld, 1995). Teachers usually give didactic lectures which cover the subject matter while facilitators aid the learners to achieve their own understanding of the content. In the former scenario the learners play a passive role and in the latter scenario the learners play an active role in the learning process. The emphasis thus turns away from the instructor and the content, and towards the learner (Gamoran, Secada, \& Marrett, 2000). This dramatic change of role implies that facilitators need to display a totally different set of skills than teachers (Brownstein 2001). Teachers give answers according to a set curriculum, facilitators provide guidelines and create the environment for the learners to arrive at their own conclusions; teachers mostly give a monologue, facilitators are in continuous dialogue with the 
learners (Rhodes and Bellamy, 1999). Facilitators should also be able to adapt the learning experience 'in mid-air' by taking the initiative to steer the learning experience to where the learners want to create value. The learning environment should also be designed to support and challenge the learners' thinking (Di Vesta, 1987). The ultimate goal is to help the learners become effective thinkers. This can be achieved by assuming multiple roles, such as consultant and coach.

Autonomous Learning has been a buzz word in foreign language education since the past decades, especially in relation to lifelong learning skills. Holec (1981) defined autonomy as "the ability to take charge of one's own learning" while Little (1991) took it as a matter of the learner's psychological relation to the process and content of learning. Benson (1996) explained autonomy as the recognition of the rights of learners within educational systems. Breen \& Mann (1997) added that autonomous learners must want to learn and develop a meta-cognitive capacity that allows them to handle change, negotiate with others, and make strategic use of the learning environment. This entails assessing wants, needs, and interests and choosing the best way to obtain these. This can best be attained in an environment in which teachers help students to discover and use effective learning strategies. From the perspective of foreign language education in China, Shu Dingfang (2004) pointed out that autonomous learning consisted of such three elements as attitude, capacity and environment. Based on the above definitions, we can define autonomous learning in foreign language education as an active and constructive process during which a learner decides on learning contents, learning plans, learning methods, learning schedule and learning environment according to his own specific needs, motives and objectives.

Many studies have been carried out to test the effectiveness of web-based autonomous learning. An empirical study by Li Chuan (2005) confirmed that a web-based evaluation model could improve the college students' self-management, self-reflection and teamwork rapidly. By utilizing listening tests, interviews and questionnaires, Lin Lilan (2006) found that college students improved their listening ability more markedly in a web-based autonomous learning environment. They also found that a web-based learning environment could stimulate the students to use more learning strategies. A comparative study by Bagheri and Aeen (2011) showed that the Iranian secondary school students in the experimental group who had been taught by the autonomous learning approach outperformed the control group in the traditional teaching classrooms in terms of English writing ability. Unfortunately, few studies have been conducted to test the effect of web-based autonomous learning on the college students' overall achievements in English study in the Chinese EFL setting.

Until the end of the 19th century, English teachers had always been dominating the classrooms as knowledge providers. However, the 20th century saw the emergence of various new teaching methods such as the audio-lingual method, the audio-visual method and the communicative method. The roles of a teacher have changed accordingly. They are not only knowledge providers but also controllers, evaluators, organizers, prompters and participants. With the computers integrating into foreign language education, Voller (1997) outlined the roles of a teacher as facilitator, counselor and resource-provider. As for the roles of a teacher in an autonomous learning setting, many studies have been carried out. For example, in a survey about the college students' views toward the roles of an English teacher in an autonomous learning classroom, Pan Jixian(2004) found that the traditional role as knowledge provider no longer suited the modern college English classrooms. In order to chase down the expected roles of an English teacher in a web-based autonomous learning setting in China, we will do some empirical research.

\section{METhodology}

\section{A. Study Questions}

The two questions addressed in the study were:

1) Does a web-based autonomous learning setting improve the college students' overall English achievements more effectively than the traditional English teaching setting?

2) What are the expected roles of an English teacher in a web-based Chinese EFL setting?

\section{B. Participants}

Eighty eight students from 2 classes in Jiangxi Normal University took part in the study. Class One Grade 2010 of the Mathematics department was the experimental group and Class Two Grade 2010 of the same department acted as the control group. Each group was made up of 44 students. Strictly speaking, the study was just a quasi-experiment because two intact classes were used as subjects. The experiment lasted two school years.

TABLE 1

A COMPARISON BETWEEN THE TWO GROUPS' COLLEGE ENTRANCE EXAMINATION ENGLISH SCORES

\begin{tabular}{|l|l|l|l|l|l|}
\hline Group & Average Score & Highest Score & Lowest Score & SD & $\begin{array}{l}\text { Independent Samples } \\
\text { T-test Sig. (2-tailed) }\end{array}$ \\
\hline Experimental Group & 94.09 & 115 & 65 & 9.79 & .679 \\
\hline Control Group & 95.26 & 126 & 61 & 15.29 & \\
\hline
\end{tabular}

Table 1 indicated that there was no marked difference between the two groups' English proficiency when they started their college study. 


\section{Instruments}

The same teaching materials published by Shanghai Foreign Language Education Press were used for both the experimental group and the control group. Both groups had 4 English classes each week and each class lasted 50 minutes. In a week, the experimental group went about 2 classes of autonomous leaning in a well-equipped classroom and the teaching material they used was the Web Teaching System of New Concept College English (new edition). They carried on listening and speaking activities autonomously through this web teaching system. They also did some preview and review work for New College English Integrated Course (new edition) which was intended for reading and writing. During the other 2 English classes in the same week, it was the teacher that carried out classroom teaching and tutoring in a multimedia classroom. However, for the control group, 2 English classes were used for the Integrated Course to teach reading and writing. The traditional teacher-centered teaching method was in the dominant position. As for the two listening and speaking classes, classroom activities were organized according to the routine practices, that is to say, the teacher decided on the listening activities and the students practiced speaking under the guidance of the teacher. What's more, different assessment systems were utilized to measure the two groups' performance. For the experimental group, formative assessment was mainly used, i.e. the students' grades in each semester consisted of day-to-day class work (60\%) and final test scores (40\%). As for the control group, it was finality assessment that played a part. The students' performance in each semester was made up of day-to-day class work (30\%) and final test scores (70\%).

After two school years' experiment, a comparison was made between the two groups' scores of Band 4 College English Test. Questionnaires were also conducted to investigate the experimental group's attitude toward web-based autonomous learning and the expected roles of a teacher in such a learning setting.

\section{EXPERIMENTAL PROCESS}

As autonomous learning is a long and dynamic process, the present study lasted two school years, that is, from the September of 2010 to the September of 2012, which covered the whole process of the participants' English classes at college. It is only in this way that we could explore the students' autonomous learning ability development thoroughly and objectively in a web-based setting. What's more, a two-year experimental process made it possible for us to fully analyze the various problems arising from a web-based setting. The details of the experiment went as follows:

Firstly, the participants in the experimental group received learning strategy training regularly, with emphasis varying from one semester to another. According to Macintyre \& Noels (1997), learning strategies help learners better comprehend and grasp learning activities as well as reduce their confusion and anxiety, which will keep them motivated and enthusiastic in the learning process. As a matter of fact, autonomous learning ability belongs to a kind of self-controlling ability. Skillful language learners, who are generally equipped with good self-controlling abilities, should have mastered the skills and strategies needed for carrying out various kinds of learning activities and solving different types of learning difficulties. They are also able to choose an appropriate learning approach according to a certain learning task. Therefore, learning strategy training and discussions about specific learning methods and skills were held regularly to help the participants in the experimental group to integrate learning strategies into their actual learning process. At the beginning of their English study, the participants in the experimental group were trained how to use mega-cognitive strategies to set long-term goals and short-term goals respectively, which included the goals of each semester and the goals of each week. They were encouraged to do a lot of reading after class to enlarge their English vocabulary. They were also required to practice their English pronunciation and intonation in a standard way. Subsequently, some cognitive strategies were explained to show them how to carry out listening, speaking, reading and writing activities effectively. Affective and social strategies were taught to help them to control and adjust their emotions, attitudes and motivations etc. Secondly, the participants in the experimental group were required to do the unit tests in the teaching system after finishing each unit. The unit test scores counted as an important part of their day-to-day class work. Thirdly, they could carry out autonomous learning activities for free after class at the College English Autonomous Learning Centre. They could also use their own computers to access the Web Teaching System whenever they were willing to. Fourthly, workshops were held at regular intervals to introduce and discuss the cultural differences between the Chinese culture and the English-speaking culture. Lastly, the assessment process was included as an organic part of the whole teaching process, according to which the performance of the participants' activities in the autonomous learning process was evaluated comprehensively. The composition of the day-to-day class work could be seen in table 2 .

TABLE 2

THE COMPOSITION OF THE EXPERIMENTAL GROUP'S DAY-TO-DAY CLASS WORK

\begin{tabular}{|l|l|l|l|l|l|l|}
\hline Exercises & $\begin{array}{l}\text { Autonomous } \\
\text { Learning After Class }\end{array}$ & $\begin{array}{l}\text { Class } \\
\text { Performance }\end{array}$ & Attendance & $\begin{array}{l}\text { Speaking } \\
\text { English }\end{array}$ & $\begin{array}{l}\text { Unit Test } \\
\text { Scores }\end{array}$ & $\begin{array}{l}\text { Self- } \\
\text { Evaluation }\end{array}$ \\
\hline $15 \%$ & $15 \%$ & $10 \%$ & $10 \%$ & $20 \%$ & $20 \%$ & $10 \%$ \\
\hline
\end{tabular}




\section{A. Questionnaire}

At the end of the experiment, a questionnaire was conducted among the experimental group to find out their attitudes toward web-based autonomous learning. All the members were present and they completed the questionnaires as requested. The result of the questionnaire was presented in table 3.

TABLE 3

A QUESTIONNAIRE ABOUT WEB-BASED AUTONOMOUS LEARNING

\begin{tabular}{|l|l|l|l|l|}
\hline Questions & $\begin{array}{c}\mathrm{A} \\
\%\end{array}$ & $\begin{array}{c}\mathrm{B} \\
\%\end{array}$ & $\begin{array}{l}\mathrm{C} \\
\%\end{array}$ & $\begin{array}{l}\mathrm{D} \\
\%\end{array}$ \\
\hline 1. What do you think of web-based autonomous learning? & 20.6 & 59 & 15.9 & 4.5 \\
\hline $\begin{array}{l}\text { 2. What do you think of its role in mobilizing enthusiasm in learning } \\
\text { English? }\end{array}$ & 25 & 52.3 & 18.2 & 4.5 \\
\hline $\begin{array}{l}\text { 3. What do you think of its role in enhancing autonomous learning } \\
\text { ability? }\end{array}$ & 22.7 & 56.9 & 18.2 & 0 \\
\hline $\begin{array}{l}\text { 4. What do you think of its role in allowing for the freedom to select } \\
\text { learning tasks? }\end{array}$ & 25 & 56.8 & 16 & 0 \\
\hline $\begin{array}{l}\text { 5. What do you think of its role in helping choose an appropriate } \\
\text { learning strategy? }\end{array}$ & 29.5 & 40.9 & 20.6 & 4.5 \\
\hline $\begin{array}{l}\text { 6. What do you think of its role in improving comprehensive English } \\
\text { proficiency? }\end{array}$ & 36.4 & 40.9 & 22.7 & 0 \\
\hline
\end{tabular}

Note: $\mathrm{A}=$ very satisfied; $\mathrm{B}=$ satisfied; $\mathrm{C}=$ average; $\mathrm{D}=$ dissatisfied; $\mathrm{E}=$ very dissatisfied

As the college students are possessed with different linguistic cognitive abilities and their levels of English proficiency are not unitary, their language needs vary with each other. Evidently, a web-based autonomous learning setting can meet the need of each student because it breaks through the restrictions of time and space inherent in the traditional English teaching methods. In this learning setting, an open space, in which the students can carry out their study no matter when and where, is constructed. They are also able to choose the proper learning materials suiting their levels of English proficiency in a convenient way. That was why $79.6 \%$ of the participants in the experimental group were satisfied with web-based autonomous learning. According to the statistics in table 3, 77.3\% of the participants thought that web-based autonomous learning could mobilize their enthusiasm to study English, which showed that this new model played a part in making them more interested in learning English and boosting their confidence. Among the participants, $81.8 \%$ of them thought that they enjoyed the freedom to choose their own learning tasks, indicating that they were entitled to the decision-making power to integrate progressively new learnt knowledge into their already learnt knowledge in a suitable way. What's more, $70.4 \%$ of the participants agreed that they were able to choose appropriate learning strategies to carry out their English study in a web-based autonomous learning setting. This proved that they could resort to their own resources to fulfill their learning tasks in this setting. As for the role of improving comprehensive English proficiency, 77.3 of them, which made up more than three fourths of the participants, were satisfied with the web-based autonomous learning setting because they improved their English proficiency remarkably.

\section{B. T-test}

After the two-year experiment, a t-test was made to compare the scores of College English Test Band 4 between the two groups.

TABLE 4

A COMPARISON BETWEEN THE TWO GROUPS' CET BAND 4 SCORES

\begin{tabular}{|l|l|l|l|l|l|}
\hline Group & $\begin{array}{l}\text { Average } \\
\text { Score }\end{array}$ & $\begin{array}{l}\text { Highest } \\
\text { Score }\end{array}$ & $\begin{array}{l}\text { Lowest } \\
\text { Score }\end{array}$ & SD & $\begin{array}{l}\text { Independent Samples } \\
\text { T-test Sig. (2-tailed) }\end{array}$ \\
\hline Experimental Group & 413.93 & 545 & 292 & 51.16 & .003 \\
\hline Control Group & 365.97 & 528 & 224 & 85.73 & \\
\hline
\end{tabular}

The above table shows that the experimental group performed much better than the control group in the test.

According to the results of the questionnaire and the t-test, we could answer the first question of our study now, that is, a web-based autonomous learning setting could improve the college students' overall English achievements more effectively than the traditional English teaching setting.

\section{The ExPected Roles of AN ENGLish Teacher In A Web-BASEd SetTing}

To make clear the expected roles of an English teacher in the Chinese EFL web-based setting, another questionnaire was conducted among the experimental group. The questionnaire was designed on the basis of Gardner \& Miller's classification of teachers' roles in an autonomous learning setting (1999) as well as the real situations of the Chinese EFL classrooms. Ten roles were listed and each role consisted of five scales. In other words, the questionnaire was made in the form of Likert Five Point Scale. For each role, the subjects were required to make a choice from the five points. The points 1-5 represent the five scales which range from "not important" to "very important". The subjects were also required to rank the 5 roles they considered most important in order of importance, which could be used to verify the result of the calculations of the Likert Five Point Scale. 
TABLE 5

AN ENGLISH TEACHER' ROLES RANKED IN ORDER OF IMPORTANCE BY THE STUDENTS IN A CHINESE EFL AUTONOMOUS LEARNING SETTING

\begin{tabular}{|c|c|c|c|c|}
\hline Role & Description & Mean & $\mathrm{SD}$ & Ranking \\
\hline counselor & $\begin{array}{l}\text { Give advice to the students about leaning methods and learning } \\
\text { strategies. Ready to answer the questions the students ask. }\end{array}$ & 4.57 & 0.68 & 1 \\
\hline facilitator & $\begin{array}{l}\text { Help the students cultivate interest in autonomous learning. } \\
\text { Encourage them to persist in autonomous learning. }\end{array}$ & 4.50 & 0.82 & 2 \\
\hline motivator & Motivate the students to actively engage in autonomous learning. & 4.07 & 0.94 & 3 \\
\hline trainer & Train the students to learn how to carry out autonomous learning. & 4.00 & 1.08 & 4 \\
\hline $\begin{array}{l}\text { textbook developer } \\
\text { and compiler }\end{array}$ & $\begin{array}{l}\text { Develop and compile various teaching materials according to the } \\
\text { students' differences. }\end{array}$ & 3.97 & 1.30 & 5 \\
\hline evaluator & $\begin{array}{l}\text { Obtain feedback by constantly evaluating the validity of } \\
\text { autonomous learning. }\end{array}$ & 3.73 & 1.20 & 6 \\
\hline planner & Help the students set learning goals and make learning plans. & 3.37 & 0.89 & 7 \\
\hline organizer & Organize the whole learning process. & 3.27 & 1.23 & 8 \\
\hline tester & Test the students regularly to check their progress. & 3.27 & 0.91 & 9 \\
\hline monitor & Monitor the students during the process of autonomous learning. & 2.90 & 1.12 & 10 \\
\hline
\end{tabular}

From the above table, we could see that six roles were considered important because their means were well above 3.5 . The other 4 roles were considered comparatively less important because their means were between 2.5 and 3.5 . This result was consistent with Pan Jixian's investigation in 2004, in which he explored the students' conceptions about autonomous learning. That is to say, the teachers were expected to be counselors, facilitators and motivators first and foremost in both studies. However, Pan's study focused on comparing the role of an instructing teacher with that of a traditional dominating teacher, if failed to highlight the specific aspects that a teacher should facilitate, help and motivate. The present study found out that the students not only longed for teachers' advice about learning methods but also hoped for teachers' encouragement and support in their autonomous learning, indicating that autonomous learners needed much perseverance to persist in their learning. That was why they searched for emotional support from their teachers now and then. The present study also found out that autonomous learners hoped to receive training about how to carry out autonomous learning. As a matter of fact, many scholars (Holec 1979; Little 1991; Nunan 1996) believed that autonomous learning was a kind of ability that could be cultivated. The students' aspiration for improving their autonomous learning ability was well confirmed in this study and the teachers were expected to fulfill their duty in this aspect in due course. Besides, the present study disclosed that the students expressed their desire for teaching materials that could well suit their autonomous learning. All these findings turned out to be of practical significance for us to improve our practices in autonomous learning. The above table indicated that the roles of tester and monitor were less important than the other roles. It seemed that the students did not want to be monitored and tested. On the one hand, the students hoped that the teachers would take measures to help overcome their inertia, on the other hand, they were unwilling to be monitored and tested by their teachers. This phenomenon demonstrated the students' ambivalent attitude toward autonomous learning.

\section{CONCLUSION}

The two-year experiment proved that web-based autonomous learning played an effective role in helping the Chinese college students improve their learning autonomy as well as their performance in the English examinations. By way of combining networks technology with college English teaching, the "teacher-centered" conception is well embodied in this setting, which can not only facilitate personality development but also the release of personal potential. Therefore, this new teaching method can well be extended to the classrooms where necessary facilities are available. However, we also found some problems in this study. First of all, not all the students were able to adapt themselves fully to the web-based autonomous learning, which goes on with flexible working hours in a fairly relaxed environment. Especially for those with poor English and week self-control ability, they made little progress in this setting. Secondly, a web-based autonomous learning setting was not conducive to improving English speaking. In that case, much research remains to be done regarding how to improve the students' self-control ability and English speaking in a web-based autonomous learning setting.

As a matter of fact, the roles of an English teacher have always been evolving dynamically with social development as well as the changes of teaching theory and teaching methodology. This kind of developmental orientation implies that an English teacher should get ready for improvement to satisfy the needs of the fast-changing society. Obviously, the transformation of an English teacher's roles can push his/her students to change their roles in their learning process and to better their learning methods, which will help to achieve the aim of personal development. Under the circumstances, the roles of an English teacher must be restructured and reconstructed in a web-based autonomous learning setting. Different roles should play different parts before class, in class and after class. That is to say, an English teacher should be a designer and a developer before class; an instructor, organizer, trainer and tester in class and a monitor and resource-provider after class. 


\section{REFERENCES}

[1] Bagheri, M. \& L. Aeen. (2001). The impact of practicing autonomy on the writing proficiency of Iranian Intermediate EFL learners. Journal of Pan-Pacific Association of Applied Linguistics (1): 1-13.

[2] Bauersfeld, H. (1995). The structuring of the structures: Development and function of mathematizing as a social practice. In L. P. Steffe \& J. Gale (Eds.), Constructivism in education (pp.137-157). N. J.: LEA, Lawrence Erlbaum Associates, Publishers.

[3] Benson, P. (1996). Concepts of autonomy in language learning. In R. Pemberton, S.L. Edward, W.W.F. Or, and H.D. Pierson (Eds.). Taking Control: Autonomy in Language Learning. Hong Kong: Hong Kong University Press. 27-34.

[4] Benson, P. \& Voller, P. Autonomy and Independence in Language Learning. Harlow: Longman.

[5] Breen, M. P. \& Mann, S. J. (1997). Shooting arrows at the sun: perspectives on a pedagogy for autonomy. In P. Benson \& P. Voller (Eds.), Autonomy and independence in language learning (pp.132-149). London: Longman.

[6] Brownstein, B. (2001). Collaboration: The foundation of learning in the future. Education, 122(2), 240-247.

[7] Di Vesta, F. J. (1987). The Cognitive movement and education. In J. A. Glover \& R. R. Ronning (Eds.), Historical foundations of educational psychology (pp. 203-233). New York: Plenum Press.

[8] Gamoran, A., Secada, W. G., \& Marrett, C. B. (2000). The Organizational context of teaching and learning. In M. T. Hallinan (Ed.), Handbook of the sociology of education (pp. 37-63). New York: Kluwer Academic/Plenum Publishers.

[9] Gardner, D., \& Miller, L. (Eds.). (1996). Tasks for Independent Language Learning. Alexandria, VA: TESOL(3): 46-58.

[10] Holec, H. (1981). Autonomy and Foreign Language Learning. Oxford: Pergamon. (First published [1979], Strasbourg: Council of Europe.)

[11] Li Chuan. (2005). An experimental research into the web-based college English teaching evaluation model. Foreign Language and Foreign Language Teaching (7): 33-36.

[12] Lin Lilan. (2006). Learning strategies and learning effectiveness in a web-based autonomous learning setting: an experiment on English listening reform in China. Foreign Language Research (2): 39-45.

[13] Little, D. (1991). Learner Autonomy: Definitions, Issues and Problems. Dublin: Authentic.

[14] MacIntyre, P.D. \& Noels, K.A. (1997). Biases in self-ratings of second language proficiency: the role of language anxiety. Language Learning, 47/2, 265-287.

[15] Nunan, D. (1996). Towards autonomous learning: some theoretical, empirical and practical issues. In R. Pemberton, S.L. Edward, W.W.F. Or, and H.D. Pierson (Eds.), Taking Control: Autonomy in Language Learning. Hong Kong: Hong Kong University Press. 13-26.

[16] Pan Jixian (2004). Learner Autonomy: Identities and Self-images. Foreign Language and Foreign Language Teaching (6): $22-25$.

[17] Rhodes, L.K\& T. Bellamy. (1999). Choices and consequences in the reform of teacher education. Journal of teacher education (50): $17-26$.

[18] Richardson, V. (2003). Constructivist pedagogy. Teachers College Record, 105 (9), 1623-1640.

[19] Sinclair B. (1997) Learner Autonomy: the Cross Cultural Question. IATEFL Newsletter, Issue 139.

[20] Su Dingfang. (2004). Foreign language teaching reform: problems and solutions. Shanghai Foreign Language Education Press.

[21] Voller, P. (1997) Does the teacher have a role in autonomous language learning? In P. Benson, \& P. Voller. Autonomy and Independence in Language Learning. Harlow: Longman, 98-113.

Qiyuan Shen was born in Ganzhou, China in 1971. He received his MA degree in applied linguistics from Suzhou University, China in 2005.

He is currently a lecturer in the School of Foreign Languages, Jiangxi Normal University, Nanchang, China. His research interests include pragmatics and second language acquisition. 